\title{
Любимова Т.Б.
}

\section{Что передается в традиции?}

Аннотация: Согласно учению о Единой Духовной Традиции современное состояние мира есть катастрофическое отклонение от нормального, то есть традиционного, состояния культуры, общества и самого человека. Это «спуск» к разрушению всех форм культурной и социальной жизни, к тому, что в традиции называется «концом мира». Традиция не есть вообще прошлое культуры, в ней сохраняются и передаются не внешние культурные формы. Передается духовное влияние, а все символы религий и все метафизические учения суть лишь более или менее неразборчивые ее отпечатки. Принимая за основу рассмотрения проблемы принци соответствия макрокосма и микрокосма, мы устанавливаем аналогию между историческими событиями, ходом истории и жизнъю человека. В силу этого можно использовать критерий здоровъе-болезнь для оценки тотального процесса истории, в особенности, представления о конще истории с традиционной точки зрения. Вне зависимости от того, занимают ли исследователи Единой Традиции трансцендентную точку зрения или нет, ими отмечается, что традищия и посвящения обладают мета-историческим и кросс-культурным измерениями.

Review: According to the teaching about the Uniform Spiritual Tradition, the modern situation in the world is a catastrophic departure from the normal, i.e. tradition development of culture, society and humankind. This is the 'decline' towards destruction of all forms of cultural and social life and what is called 'the end of the world'. Traditions are not the past of culture. Traditions retain and convey internal cultural forms. They also translate the spiritual influence and all symbols of religions and all metaphysical teachings are more or less readable prints thereto. Focusing on the problem of the relation between the macrocosmos and micocosmos, the author of the article draws the analogy between historical events, the course of history and man's life. For that purpose the author uses the 'health-sickness' criterion for evaluating the overall historical process, in particular, concepts of the end of history from the traditional point of view. Disregarding the fact whether researchers of the Uniform Tradition follows the transcendental point of view or not, they all note that tradition and consecration have meta-historical and cross-cultural dimensions.

Ключевъе слова: Традиция, духовное влияние, посвящение, принци, символ, здоровъе, Восток и Запад, современная культура, метафизика, история.

Keywords: Tradition, spiritual influence, consecration, principle, symbol, health, East and West, modern culture, metaphysics, history.

\section{Комментарий главного редактора}

Читатель, вероятно, ожидает от статьи Любимовой привычную научную рефлексию. Но, вдруг, неожиданно попадает в странную реальность: здесь перемежаются дискурсы, принадлежащие как высокой философской традиции (да, опять традиция), так и совершенно к другой традиции - эзотерической. Но связь философии и эзотерики только на первый взгляд случайная. Философия отца философии Платона, с точки зрения, современных исследований, может быть понята и как первое на культурной европейской почве эзотерическое учение. Примерно в то самое время на восточной культурной почве создается учение Готамы Будды, которое тоже очень философично. Дискурс Любимой непривычен, но только если не знать восточные эзотерические учения. Как я показываю в своих работах, например, книгах «Путешествие в страну эзотерической реальности. Избранные эзотерические идеи» (1998) и «Эзотерический мир. Семантика сакрального текста» (2002), идеи, которые обсуждает Любимова, широко распространены в интеллектуальной традиции Востока. Но даже если не знать этой эзотерической традиции, статью Татьяны Любимой нетрудно понять (было бы желание), поскольку пишет она очень ясно. Кроме того, можно указать своеобразный ключ к адекватному пониманию: это критика нашей культуры и ее вмененностей, которые сегодня кажутся очевидными, а также поиск выхода из тупика и разрешения монблана проблем, разрушающих нашу жизнь. 


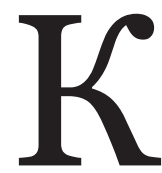
азалось бы, ответ на этот вопрос чрезвычайно прост: передается то, что не меняется во времени. Но во времени меняется все. Что может остаться не задетым временем? Только то, что есть само время. Все в нем, а оно ни в чем. В нем развертываются множественные состояния бытия и всех его вещей, множественность в истории, в отношении которой обычно и понимается этот термин. Но история игрок коварный, она играет краплеными картами, передергивает, так что непосредственно традиция неразличима.

Слово «традиция», как правило, используется неточно. Философия - это не математика, и точность не есть ее достоинство и преимущество. В ней требуется другая точность. Иначе и быть не может, потому что, в отличие от специальных наук, она мыслит о том, что никем не имеется в виду, что кажется лишним. Философская мысль - это разведчик неведомого, сталкер, научная мысль - преследователь определенной вещи, предмета; ученый отчасти уже знает, что он исследует, поэтому наука, вопреки видимости, во многом догматична. Философия же, пробудившись от догматического сна, оказалась вне закона, как истинная любовь к истине (то есть замкнутая на себе: как писал Сенека: философу никто, кроме него самого, не нужен). Прошлое для нее не есть закон. Она всегда начинает сначала, от начала, которое не где-то в истории мысли и культуры, а в самом философе. Он начинает от самого себя, вопреки идее Ф.Шлегеля о том, что философия есть история философии. И при этом она есть образ традиции, как самопознающий и реализующий себя дух (если по Гегелю) но не в ее современном состоянии, которое ближе к филологии, то есть бесконечному поиску тончайших оттенков слов, а в виде первофилософии, о которой упоминал Аристотель.

В обыденном употреблении нашего термина, в социальных науках под словом «традиция» понимается что угодно, сохранившееся от прошлого в настоящем, или достаточно долго сохраняющееся в качестве культурного образца. Обычаи, обряды, способы изготовления вещей, привычки и разнообразные культурные объекты, лишь бы они воспроизводились в течение более или менее долгого времени. Очевидно, что все это может относиться только к изменчивому миру, в котором само постоянство непостоянно. Такое понимание традиции есть следствие метода исследова- ния, распространенного в социальных науках. Если доминирует эмпирический и обобщающий стиль мышления, то мы получаем неудовлетворительный ответ: «вещи», свидетели прошлого, какая-нибудь избушка на курьих ножках ${ }^{1}$, факты и события прошлого называют традициями, в то время как это просто отрезок, нечто вырезанное из бесконечного потока форм, событий и имен.

То, что некогда называлось первофилософией, отправляется из другой точки, от начала, исходит из замкнутого на себя метафизического принципа, полагая все эмпирически данное лишь следствием. Но где он, этот исходный принцип? Каков он? На сей вопрос можно ответить так: достичь исходного принципа при современном состоянии человечества можно только в цепи посвящения. Рене Генон, который создал всеобъемлющую концепцию Единой Духовной Традиции, утверждал, что исходный изначальный принцип единства Традиции как таковой сформулировать невозможно. В разных культурах, метафизических учениях, религиях мы имеем только ее отпечатки, более или менее частные аспекты. Но все они в своем эзотерическом ядре восходят к изначальному принципу. В историческом времени полнее всего традиция запечатлена в Индии и в Китае, на Западе цивилизация сохраняла связь с традицией вплоть до средневековья, с уходом которого с исторической сцены, ее поддерживали посвященческие организации. Однако в современном мире, похоже, и на Востоке антитрадиционная культура постепенно оттесняет традиционную в этнографическую резервацию. Надо еще отметить, что современные исследователи отождествляют культуры диких племен, находящихся в примитивном состоянии, с традицией. Согласно Генону, напротив, это деградировавшие племена, давно отделившиеся от основного ствола традиции, которая всегда носит высоко интеллектуальный характер, снижение умственного уровня ведет и к социальной, и к психологической, и даже физической деградации. Эволюционизм, доминирующий в объяснении не только природных процессов, но и социальных, блокирует понимание этого факта.

\footnotetext{
${ }^{1}$ Согласно обычаю, под порогом у входа в дом закапывали эти самые ножки, косточки. Со временем все обычаи меняют смысл на нечто неузнаваемое. Может быть, некогда это было знаком призыва дракона-хранителя? Стража?
} 
Поскольку изначальный принцип как таковой нам недоступен, то мы можем обратиться к тому общему (в смысле распространенному по всему миру, среди разных народов и культур) принципу, который утверждает аналогию между устройством Вселенной и человека, макрокосмом и микрокосмом. Причем это также аналог и между ходом жизни отдельного человека и судьбой Вселенной, как его формулировали древние: «всё во всём, но в каждом особым образом». Прочитывается он сквозь информационный шум, который, возможно, есть шум только для нас: поскольку мы слушаем одну волну, постольку другие создают шум, в котором тоже информация, но не прочитываемая на нашей волне ${ }^{2}$.

Что означает в этой известной формуле «особым образом»? «Особость» психологически задана информационными фильтрами. Мы видим и слышим - чувственно и умственно, - пребывая внутри неких ограничений. Есть три измерения, в которых мы воспринимаем физическое пространство (не теоретически, а то, что дано в опыте как физическое пространство). По аналогии мы можем выделить три (по крайней мере) измерения в психологическом пространстве при так называемом нормальном состоянии психики. На отклонения от нормы с легкостью можно указать, но на саму норму - невозможно.

Три психологических измерения суть полярные (вокруг полюса, т.е.) распределения с придаваемыми им, распределениям, знаками, как бы пропусками, паролями. Каковы эти измерения? 1. Есть шкала утверждениеотрицание, да-нет, свой-чужой, только информационная. 2. Шкала радость-огорчение, эмоциональная: можно назвать ее энергети-

\footnotetext{
${ }^{2}$ Мне показались интересными замечания рецензента, Безуглова В. В., д. хим. н., зав. лаб.одного из наших академических институтов, которому $я$ показала статью перед публикацией. Помещаю их в сносках и выделяю курсивом. «Если понимать информационный шум как множественность информационных волн, то слушание и слышание только одной волны этот шум не заметит. Мы не видим ультрафиолет и испускаемые некоторыми животными ультрафиолетовые лучи нам не видны. Это не шум. Шум возникает тогда, когда ценная информация погружена в обилие в данный момент бесполезной, но слышимой информации, которая может затушевывать и даже искажать ту, нужную и ценную. Другое дело, что Традиция, как реликтовое излучение, присутствует всегда и во всём, но нужно иметь особым образом настроенный прибор души, чтобы это слышать» (Безуглов В.В.).
}

ческой, поскольку эмоции тесно связаны с жизненной энергией, в них энергия окрашивает голую информацию. Люди, у которых заторможена эмоциональная жизнь, жизнь чувств, похожи на дальтоников в визуальном пространстве. Таковых много, каждый десятый человек мужского пола на нашей планете. 3. Шкала очарование-разочарование; она отлична от эмоциональной тем, что здесь включаются импульсы тонкого мира, Тонкий мир объемлет физическую и психическую составляющую человека, но не только. Он одновременно и субъективен, и объективен, существует реально, мы в нем живем так же, как в физическом, хотя при обычном состоянии наших органов чувств мы его не воспринимаем.

Конечно, эта троичная двойственность выделяется отчасти условно, схематично. Можно как-то иначе сконструировать гипотезу об информационных фильтрах, но они существуют. Важно, что и тот и другой срез, или план заданы устройством бесконечно сложной информационной организации, которую мы называем человеком. Через посредство этих планов-срезов мы все без исключения в качестве родовых существ общаемся с миром, а точнее, с Вселенной, аналогом коей мы и являемся. Это устройство троичной двойственности есть одновременно канал связи и фильтр, ограничитель. Духовное существо, проявленным отпечатком которого является физическое тело человека, неизмеримо превосходящее физическое и психическое ограниченное состояние, есть целостный человек, но фильтры (в том числе и сознание 3 ) отсекают от нас знание об этом целостном составе человека, каждого из нас.

Тонкий мир в определенной мере всеобъемлющ, но не универсален, так как существует еще различение тонкого и духовного, а также проявленного и не проявленного. Их смешение есть следствие как раз отступления от традиции, которую мы продолжаем иметь в виду. И все это присуще человеку, который к универсальной традиции как будто подвешен, сама же традиция есть проявление изначального принципа, как уже сказано.

Если придерживаться традиционного учения, которое в западной науке называют индуизмом, то наша современность есть темные

\footnotetext{
3 «Я бы в скобках написал (в том числе и стереотипы сознания) поскольку сознание, воспринимающее Знание от Посвященного, наоборот, если и не разрушает фильтры совсем (наверное, это и невозможно), то сильно раздвигает рамки» (Безуглов В. В.).
} 
века. Иными словами, «Духовный Свет», который является сутью и основой всего проявленного мира, не достигает сознания большинства людей, живущих в такие темные времена. В прежние, начальные циклы все было пронизано духовной традицией. Не было необходимости деления на варны, такое состояние общества называется «над варнами». Понятно, что не было нужды и в посвящении. Современное же состояние мира - это состояние мира «вне варн» (или «под варнами»), когда доступ к традиции затруднен и духовная иерархия, существовавшая в предшествующую югу, разрушена. Обычно, сравнивая западную и восточную ментальность, берут их как нечто данное, то, что можно сравнивать по известным параметрам (выстроенным, разумеется, из специфических характеристик нашего же мышления). Это круг, из которого невозможно вырваться, как кажется. Так вот, исходя из приведенной выше оппозиции, эти два полярных состояния нельзя сравнивать, у них нет общего поля, на котором они были бы представлены. Ведь для культуры и сознания людей Востока определенная реальная или виртуальная духовная иерархия сохраняется каким-то непостижимым для нас образом.

Итак, в современном мире, в котором доминирует западная культура, отсутствуют посвящение, духовная иерархия, передача духовного влияния; это состояние «под варнами». В нем все есть карикатура на традицию. Наука, искусство, в меньшей степени религия, хотя и она тоже в силу своей ограниченной точки зрения (религий много, а истина - одна) тоже есть одна из ступеней спуска от традиции к профанному миру. Надо отметить, что восточные метафизические учения Генон не называет религиями. К последним принадлежат только иудаизм, христианство и ислам. В них традиционно только их эзотерическое ядро, а внешняя сторона, обращенная к социуму, то есть мораль, обычаи, не есть сама традиция, а только ее следствие, внешнее ее приложение. Хотя соотношение внешнего и внутреннего (эзотерического) в каждой из этих религий различно, традиция в каждой из них присутствует по-своему. Относительно восточных учений он тоже проводит различение эзотерического и экзотерического, но именно постольку, поскольку они существуют в историческом времени, когда посвящение уже ${ }^{4}$

\footnotetext{
4 «А может ли вообще религия быть духовным центром в высоком понимании духовного. $\mathrm{Ha} \mathrm{ca-}$ мом деле, она как раз отгораживает человека
}

Духовное влияние, передаваемое в посвящении, очевидно, есть действие некой «высшей реальности», Божественной реальности, если применить религиозную точку зрения. Следовательно, оно имеет нечеловеческий источник, это влияние приходит как бы сверху, подобно лучу света, обнаруживающему дотоле скрытые «предметы», потенции. Это луч, не зависящий от нашего волеизъявления: «Дух дышит, где хочет». Влияние не подвержено никакому принуждению «снизу», оно для него недоступно и неуязвимо. Тем не менее, посвящаемый не пассивен, он активен ${ }^{5}$, но это не внешняя деятельность, последняя может быть только следствием.

Доступ к высшей реальности, реализуемый через посредство посвящения, не имеет отношения к магии, отличен и от мистического пути, который является индивидуальным религиозным опытом. Если говорить о магии, которой так увлекаются наши современники, то в традиционном смысле, магия всегда была наукой именно материального (в широком смысле, то есть плотного и тонкого) плана бытия. Она относилась к священным наукам, которыми профанам заниматься не рекомендуется, даже опасно. И не только потому, что те не ведают, что творят, но также и потому, что они привлекают такие силы, действие которых не смогут остановить. К таким традиционным наукам относилась и алхимия, астрология, священная география и священная история и другие знания, о которых мы теперь не можем иметь никакого представления, в силу того, что связь с их единым источником прервана. От некоторых из них в наше время остались только формальные оболочки. Таким образом, законного приложения традиционных наук в настоящее время нет. Современные науки не прикреплены к единому духовному источнику, они опираются на опыт в физическом мире ${ }^{6}$. А поскольку они претендуют на знание и эффективное действие вне цепи посвящения, то они оказались именно в такой же ситуации, как и «ученик мага», подслушавший заклинание, запустивший разрушительный процесс и не смогший его остановить, так как обратного заклинания он не знал. С точки зрения традиции этот процесс -

от духовного, заменяя его суррогатом, придуманными историями, и отодвигает человека от Традиции» (Безуглов В. В.).

5 «Это воля к смыслу Франкла? (Безуглов В.В.)

${ }^{6}$ «Они вообще не связаны с духовным миром как таковым» (Безуглов В. В.). 
научно-технический прогресс, - запущенный учениками мага, в том виде, в каком он реализуется, неизбежно ведет к вселенской катастрофе (слово катастрофа буквально означает поворот, падение, крах, даже смерть).

То же можно сказать и о различии между мистицизмом и восприятием духовного влияния, которое есть необходимое условие посвящения. Мистицизм принадлежит религиозной сфере, тогда как посвящение не входит в эту сферу, хотя ритуалы крещения, рукоположения по форме суть ритуалы посвящения, аналогичные «второму рождению» и жреческому посвящению; «благодать» воспринимается как нисхождение Духа. Но, по сути, это нечто совершенно иное, так как религия и ее ритуальные формы имеют в виду только индивидуальное «спасение», а не «освобождение», прежде всего освобождение от индивидуальных ограничений. С религиозной точки зрения индивид должен быть спасаем в его индивидуальных особенностях, в его «таковости». Мистик, таким образом, имеет только индивидуальный опыт, к тому же он всегда остается пассивным по отношению к этому опыту (всегда неизвестно, когда и откуда придет мистическое «откровение»7), хотя это не означает, что это «пустой» опыт, не имеющий никакого коррелята в духовной реальности, просто он не выходит за границы пассивности и индивидуальности. Посвящение же предполагает некую внутреннюю работу, посвящаемый должен быть «готов», обладать определенной духовной квалификацией.

Это краткое различение необходимо было сделать для того, чтобы развести смыслы, которые кажутся близкими, но на деле ничего общего не имеют с духовным влиянием и его передачей в посвящении, что составляет неотъемлемую часть традиции.

Передача в цепи посвящения реализуется сверху, источник его нечеловеческий, в этом смысл духовной традиции (традиция и есть передача). Поэтому между теми традиционными

\footnotetext{
7 Достаточно вспомнить Я. Бёме и его внезапное прозрение, когда он в одном блике увидел «весь мир». Вероятно, что именно этот широко известный факт вдохновил Х. Борхеса написать свой знаменитый рассказ «Алеф». С одной стороны, это мистический опыт, но не надо забывать, что Бёме называл себя «тевтонцем», то есть уже был посвященным. В его мистическом опыте удивительным образом открывались метафизические истины, что доказывает «объективность», в принципе, возможную и в мистическом опыте, если имеется соответствующая квалификация.
}

формами (в той или иной культуре), которые оживляются присутствием духовного влияния, нет так называемой исторической преемственности, как обычно понимает процесс взаимодействия культур светская антропология, история, философия культуры. Эти традиционные культуры зажигаются подобно звездам на небе, связь между ними эмпирически не необходима. Это метафизическая связь, традиционные культуры связаны между собой не посредством наличных форм и не исторической преемственностью, а единым принципом, который не открывается во внешних формах. Но с другой стороны, существует и передача по горизонтали, от учителя к ученику. Существует «цепь посвящения», развернутая во времени, парампара. Она обеспечивает единство традиции «снизу», в проявленном мире. В этом смысле великие памятники традиции можно рассматривать как символы сразу двух принципов передачи духовного влияния. Единство больших традиционных культур, «миров», дальневосточного, индийского, христианского, иудейского, исламского (в той мере, в какой они оставались традиционными) удерживается именно таким образом.

$* * * * * * * * *$

В индуизме, как известно, Махабхарата, эпизод из которой мы возымем в качестве примера, считается Пятой Ведой. Прежде всего сам рассказ о Великой Битве идет во время «жертвоприношения змей», которое длилось 12 лет. То есть сам рассказ есть часть этого ритуального действа. Это, следовательно, как и весь ритуал, тоже есть символ, включенный в символическое действо. Символ, по сути, есть жест, указывающий вверх, в «другой мир»; ритуал - это развернутый во времени тоже жест. Мантра - звуковой, янтра - визуальный символ. В конце концов, весь мир есть символ, по словам Гёте. И такова в целом традиционная точка зрения. Символ не есть знак, поскольку означаются предметы мира форм и имен (нама-рупа); беспредметное не «значит», но оно может символизироваться, на него указывает повернутая к нам, внешняя сторона символа, то есть знак. В символе свернут (для прочтения не рассудком или разумом, а только интеллектуальной интуицией) путь восхождения от низших состояний к высшим, вплоть до Высшего Тождества ${ }^{8}$. Тогда человек ото-

${ }^{8}$ В христианстве тоже есть этот момент, он носит название «обожение». В буддизме - найти в себе «природу Будды». Наверное, можно привести и 
ждествляет себя с Высшим Принципом, высшей реальностью, однако, тогда он перестает быть видимым, слышимым, узнаваемым в мире форм. В суфизме, к примеру, утверждается, что «суфий - это тот, кого нет»9. Таким образом, символ есть средство, связывающее все планы бытия (в соответствии со ступенями посвящения), начиная от множественности телесного мира и до Единого Духовного Начала, в согласии с законом вселенской аналогии $^{10}$ (для нас - это аналогия между микрокосмом и макрокосмом). То есть, это средство восхождения снизу вверх, и средство передачи духовного влияния сверху вниз. Таким образом, символизироваться может высшая реальность, а не природные явления. Напротив, все природные явления суть символы.

Каждый эпизод в Пятой Веде может быть, таким образом, истолкован в этом смысле символически. Для западного читателя весь огромный объем рассказанных там историй представляется эпосом. Но ведь и каждый эпос тоже символичен. Если весь мир - символ, то само собой, история тоже есть символ. Мы возьмем сюжет, связанный с передачей духовного влияния (посвящением). Одним из внешних признаков посвящения является здоровье и долгожительство. Дрона, наставник и учитель великих воинов, кауравов и пандавов, в возрасте 85 лет, будучи главнокомандующим огромного войска, сражался, как 16-летный юноша. Другим признаком может быть способность по своей воле, согласно обету прайя, уйти из жизни без насилия над своим телом, одной силой йоги. Так и собирался закончить свою жизнь Дрона. Но надо добавить, что эти способности, так же как и любые другие «дары», полученные при посвящении (часто с помощью духовной практики, подвигов), не есть цель посвящения, напротив, как правило, их не следует проявлять и да-

другие аналоги. «Совершенный человек» в исламе, в дальневосточной традиции «истинный человек», «Трансцендентный человек» это вершина, пик всех подобных отождествлений» (см. об этом: Генон Р. Великая триада. М., 2010). Яркий пример Высшего Тождества - Хусейн ибн Мансур Халладж, говоривший о себе «Я есмь Истина». Что Руми прокомментировал так: « Слова «Я есмь Истина» - это лучи света на устах Мансура, а «Я есмь Господь», исходящие от фараона, - это тирания» // Услышь флейтиста. Суфии о суфизме. М., 1998. С. 158.

9 Вот Обращение к собранию суфиев д-ра Джавада Нурбахша: «Я настолько потерял себя / в поминании Тебя, / Что ищу вестей о самом себе / у всех, кого встречаю на пути» // Там же. С. 49.

${ }^{10}$ Сейчас его называют голографическим принципом. же обнаруживать. Но дело в том, что «битва» есть как бы очередное испытание, и оно как раз и обнаруживает, на какой ступени находится посвящаемый, в частности, и по этим внешним признакам. Такими же признаками духовной ступени является владение божественным оружием. Примеров такого оружия в Махабхарате множество, иногда просто невероятное оружие, вплоть до экологического (джьйотиша, агнея, адиться и т.п.).

Однако самым показательным эпизодом в этой связи (обнаружения духовного влияния) является смерть Дурьодханы, одного из главных героев битвы. Он получил телесную неуязвимость в результате передачи духовного влияния от своей матери, Гандхари, которая в течение многих лет предавалась аскезе, получив в дар огромную духовную силу (как бы мы сейчас сказали, энергию). Но в момент ее передачи Дурьодхана был отвлечен мирской заботой, точнее, чувством стыда, которое было ему внушено извне, Кришной (тот, воюя на стороне врагов, внушил ему стыд, и он прикрыл часть своего тела, бёдра, листьями, ибо не мог предстать перед матерью обнаженным). Это и стало причиной его гибели, его ахиллесовой пятой. Реальность его качеств как великого воина оказалась недостаточной для восхождения на более высокую степень посвящения. Ложная мысль, привнесенная извне (хотя по обычным представлениям она была правильной, моральной), оказалась «зазором», причиной несовершенства передачи духовного влияния. Воин стал уязвимым и погиб.

Само влияние всегда совершенно, но посвящаемый может быть недостаточно готовым, недостаточно квалифицированным. Все моменты воинской этики (кодекса чести) в традиционной культуре следует понимать не как просто договор, хотя перед битвой стороны и договариваются о правилах ведения боя, а как моменты посвящения, как ритуалы и символы, реализуемые на уровне действия (поскольку есть еще жреческое посвящение, реализуемое на уровне созерцания, действенного недеяния, у-вэй, если воспользоваться даосской терминологией). К таким моментам относится непреложное соблюдение данной клятвы: ведь клятва дается не столько перед лицом других людей, сколько в присутствии богов. Бога нельзя обманывать, это означало бы прервать нить духовного влияния. Хотя полученное посвящение нельзя потерять ${ }^{11}$, в то же самое время несоблюдение

\footnotetext{
${ }_{11}$ Здесь также присутствует момент, различающий религиозную точку зрения от чисто традиционной. «Благодать» временная, ее надо возобновлять, «бла-
} 
клятвы свидетельствовало бы о том, что оно еще не реализовано, а остается виртуальным. Так можно интерпретировать практически любой эпизод поэмы. Единство ее не только тематическое, стилистическое, эстетическое или еще какое-либо. Оно символизировано, как мы сказали вначале, тем, что рассказ ведется в «священном времени», то есть во время ритуала жертвоприношения.

Итак, духовное влияние, получаемое в ситуации посвящения, ведет человеческое существо к трансцендентному состоянию. Это состояние реализуется только через «центр» этого существа («битва» проявляет, насколько к этому центру приближено конкретное существо, участник битвы). Цели посвящения служат духовные практики, смысл которых низведение ума в сердце (центр целостного существа, находящийся вне проявленного мира). Путь посвящения, таким образом, ведет существо через этот центр (что и называется вторым рождением, обретение высшего знания) к Высшему Тождеству через преображение всего состава этого существа.

Важно также отметить, что в Великой Битве принимают участие все боги. Например, говорится, что Рудра-Шива идет впереди Арджуны и все сжигает на своем пути, получается, что Бог уже предуготовил победы героя. Вишну-Кришна тоже самый активный участник сражения. Везде участвуют боги. Все полно богов. Если вся битва есть символ, развернутый во времени (равно во времени рассказа, также и в реальном времени - ведь были реальные битвы, но и в священном времени жертвоприношения тоже), то и боги отмечают своим присутствием путь и порядок низведения духовных влияний, путь посвящения.

Итак, цепь посвящения через низведение в наше существование духовного влияния удерживает от окончательного уничтожения человечество и саму Вселенную ${ }^{12}$ Как же все это разворачивается во времени? И что характерно для современного состояния с точки зрения учения о традиции?

Компактно этот вопрос освещается в книге Р. Генона «Царство количества и знамения времени». Наше эпоха есть время завершения

гословение» вообще можно утратить. Хотя и то и другое может рассматриваться как аналог духовного влияния и даже предполагает его с необходимостью. 12 «Может, здесь надо еще раз напомнить о связи человечества и Вселенной, так что разрушение одной части - человечества, неминуемо разрушит (а как же Миры стабильности и Высшие духовные силы?) или существенно изменит Вселенную» (Безуглов В. В. ) цикла, причем конец этого конкретного цикла (юги) совпадает с концом большого цикла (манвантары), поэтому наше время есть также конец всего человечества, по крайне мере в том виде, в каком оно существует сейчас. Общие циклические законы мира и человечества обнаруживаются в этом моменте перехода, который для данного цикла есть «конец света», и в этот момент исчезновения нашего мира непосредственно возникает новая манвантара, «золотой век», поскольку золотой век есть изначальное состояние мира и человечества. Он «отделен от нашей эпохи «барьером», поистине непроницаемом для профанов, которые об этом говорят и которые не ведают того, что они говорят, когда возвещают близкий приход «новой эры», относя его к современному человечеству. Их ошибка, доведенная до самого крайнего предела, будет ошибкой самого Антихриста, претендующего установить золотой век через воцарение «контртрадиции» и создать самым обманчивым и самым эфемерным способом его видимость через подделку традиционной идеи «Священного Царства» (Sanctum Regnum); ... Разумеется, «барьер», о котором мы только что говорили и который в некотором роде должен тех, для кого он существует, совершенно закрыть внутри настоящего цикла, является препятствием еще более абсолютным для представителей «контртрадиции», чем для простых профанов, так как, будучи устремленными исключительно к распаду, они поистине суть те, для кого ничего не будет существовать по ту сторону цикла, и таким образом, для них в особенности его конец должен быть реально «концом мира» в самом полном смысле, какой только можно придать этому выражению» ${ }^{13}$.

Ответим на поставленный вначале вопрос: что же передается в традиции, передается сквозь все изменчивые культурные формы? Передается сама неизменная духовная традиция, а все символы религий и все метафизические учения, то есть фактически все, что наполняет культуру, суть лишь более или менее неразборчивые ее отпечатки. Их особость, своеобразие нами обычно считается ценной, и действительно, это своеобразие обладает ценностью, но какой? Отнюдь не сами по себе имеют смысл эти особенности и частные воплощения. Они суть фрагменты единой всеобъемлющей формы времени, представляющей собою Универсальное существование.

${ }^{13}$ Генон Р. Царство количества и знамения времени. М., 2011. С. 293-294. 
Даже самые ужасающие черты современного мира, полностью негативного, как представляется, неким непостижимым образом «работают» на восстановление традиции. Современный мир ей активно враждебен, он сражается против вечной традиции: «Это царство «контртрадиции» есть на самом деле то, что очень точно обозначено как «царство Антихриста»;... после «эгалитаризма» нашего времени будет заново утверждаться явным образом иерархия, но иерархия перевернутая, то есть, собственно, «контриерархия», вершина которой будет занята существом, которое реально ближе, чем кто-нибудь другой, соприкоснется с «инфернальными безднами». Это существо, даже если оно появиться в форме определенной личности, реально будет скорее символом, чем индивидом, как бы самим синтезом всего перевернутого символизма, используемого «контрпосвящением», что проявится в нем тем более полно, что в этой роли он не будет иметь ни предшественника, ни последователя; чтобы выражать, таким образом, ложь в ее последней степени, он должен быть, можно было бы сказать, полностью «фальшивым» со всех точек зрения и быть как бы инкарнацией самой лживости» ${ }^{14}$.

\section{$* * * * * * * * *$}

«В мире каждый день и каждый час идет настоящая война. И идет она на протяжении тысячелетий. И развязал эту войну пришедший на Планету человек. Он ведет ее с самим собой, со своими братьями и сестрами, с Планетой, с Солнцем, с вселенной, с Самим господом! Возникновение болезни - один из убийственных результатов этой войны» ${ }^{15}$.

«Болезнь - это название драмы, которая ежедневно разыгрывается в каждом уголке нашей Планеты, в каждой ее точке. Болезнь - это имя врага, который с каждым днем укрепляет свои позиции, готовясь задушить-уничтожить все живое на Земле. Болезнь - это результат жизни и «разумной» деятельности человека» ${ }^{16}$. За этими словами стоит разработанная концепция здоровья, процесса выздоровления, опирающаяся на определенную метафизическую доктрину. Поэтому мы без особой натяжки можем провести аналогию

\footnotetext{
${ }_{14}$ Там же. С. 288-289.

${ }^{15}$ Коновалов С. С. 500 важных мыслей для здоровья и счастья. М., 2014. С. 223.

${ }^{16}$ Там же. С. 222.
}

между развертыванием событий в масштабе «большого времени» макрокосма и судьбой каждого человека в смысле подверженности его старению и болезни.

Конечно, когда проводят параллели между организмом и социумом, то это всего лишь метафора, аналогии между ходом вселенских событий и жизнью человека, или между историей народа, страны, человечества и жизнью индивида тоже метафора. Но не совсем. Поистине для них существует общая мета-форма, и состоит она не в том, что вначале нечто зарождается, будучи слабым и нуждающимся в заботе, питании и воспитании, затем обретает силу, способность относительно самостоятельного действия, затем вновь слабеет, претерпевает разрушительные процессы и умирает. Это только видимость. Общая мета-форма для всего подобного, к чему можно приложить в каком-то смысле определение «жизни», состоит в том, что живое имеет в себе центр, некое «само», завернутое в самом себе и на себя, не обнаруживаемое как таковое. В наибольшей степени это «само» определяет жизнь человека, в том числе его организма, это поистине «мир в себе и для себя». Социум имитирует наличие такого центра, отсылая к «высшим ценностям» или даже к трансцендентному. В современном обществе институты культуры, занятые таким возвышением, религия, искусство, философия, отчасти и наука, существуют сепаративно, вне друг друга, и хотя они, конечно, связаны единой ментальностью и «духом времени», но вне положены друг относительно друга, ориентируясь на свои «предметы» и заявляя собственные особые ценности, вокруг которых они и строятся. Причем ни один из этих институтов не может выступить как подлинный интегратор целого. Требуется насильственное удерживание частей в единстве, то есть государство. Как смирительная рубашка для сумасшедшего. То же самое и для человечества в целом. В традиционном же обществе (разумеется, реконструируемом в идеальном пространстве и времени, но следы которого можно обнаружить и в истории) этой внеположенности не могло быть, так как все целое общества, культуры и человека было задано трансцендентным центром, «которого нигде нет», а окружность повсюду, поскольку она - множественность. Такое общество с большим основанием можно считать устроенным по принципу живого организма, нежели современное, которое организовано по механическому принципу, как машина, до- 
вольно громоздкая и бестолковая. И само это устройство может считаться претерпевающим разрушительные процессы, внеположенность частей - а мы воспринимаем такое состояние как естественное - есть знак распада; механизм для живого есть смерть. Конечно, это не один признак, есть множество других симптомов, а самый точный диагноз дан Р. Геноном, потому что он непостижимым образом занимает ту самую запредельную позицию, с которой многое видно и становится на свои места.

Любой технический объект развернут вовне, все его части, детали внеположены друг другу, он не имеет того центра, который бы связывал этот объект с тонким миром и через него с духовной Вселенной. Техно-мир никогда не будет иметь «зерна» вечности, ничто из него не может проникнуть сквозь «барьер», отделяющий наш «эон» от Нового Неба и Новой Земли. Этим зерном может обладать только живой человек, не разрушивший себя, не превратившийся в машину. Но, если продолжить аналогию со здоровьем и болезнью, то обращение к техническому способу решения проблем человечества соответствует в медицине лечением медикаментами. Средневековый принцип гласил: medice, medica mente non medicamentis, то есть «врач, лечи умом, а не медикаментами». Сейчас производят все новые и новые лекарства, и параллельно с этим увеличивается список новых болезней. Болезнь не побеждается. Но принимает все более коварные формы: «Не зная практически ни одного механизма развития хронической патологии, медицина смело и в «лоб» атакует то, чего не видит и не слышит, даже не представляя себе масштаба «противника» (его размеров) и, в конце концов, его силы. И получается, что, пытаясь урезонить спящего в организме монстра, карлик, разбудив его своим криком или легким уколом, оставляет организм наедине с ним. Но только монстр, проснувшись, становится еще более разъяренным, более агрессивным и изощренным ${ }^{17}$. В точности по этой же схеме действует человечество с социальными силами, с культурой, со своей историей. То есть не ведает, что творит. И не знает, как же это разведать.

Мы обычно нашу собственную ситуацию полагаем как естественную, нередко даже как должную, потому оценки наши сомнительны и познавательные горизонты сужены. Но как же оставить частную точку зрения? Поскольку мы не покидаем частной позиции, то все

\footnotetext{
${ }^{17}$ Там же. С. 194.
}

явления для нас оказываются либо пагубными, либо благотворными. Оставаясь на этой точке зрения, мы можем занять срединную позицию - нейтральную. Но, оставаясь в плену дуализма, человек отрицает Единство, «которое для них есть, на деле, как если бы его и вовсе не было» ${ }^{18}$. Рене Генон так устраняет это затруднение: двойственность (пагубный и благотворный аспекты) есть ключ традиционного объяснения условий проявления. Ели рассматривать ход проявления сам по себе, в особенности к концу цикла, то он представляет собою «спуск», нарастание негативных явлений, то есть обнаруживает пагубный аспект, «прогрессивную» деградацию. С другой стороны, помещенный в ансамбль универсального существования, он обладает и позитивной ценностью, которая состоит в том, что развертывает его до конца, включая низшие возможности «тёмного времени», чтобы все результаты цикла были интегрированы и как бы исчерпаны. Конец одного цикла станет началом нового. «Так же обстоит дело, когда рассматривают сам конец цикла: с частной точки зрения ... этот конец, естественно, «катастрофичен» в этимологическом смысле этого слова, указывающего на идею внезапного и непоправимого «падения»; но с другой стороны, при которой проявление, исчезая как таковое, оказывается приведенным к своему принципу во всем том, что оно имело от позитивного существования, тот же самый конец, обнаруживается, напротив, как «восстановление», через которое, как мы уже говорили, все вещи не менее внезапно будут вновь поставлены в «первоначальное состояние». Впрочем, это может применяться ко всем ступеням, идет ли речь об одном существе или о мире: в сумме, частная точка зрения всегда «пагубна», а точка зрения «тотальная», по крайней мере в большей степени, чем первая, благотворна, потому что всякий возможный беспорядок таков лишь постольку, поскольку его рассматривают сам по себе и «отдельно», и потому что эти частные беспорядки полностью исчезают перед лицом всеобщего порядка, в который они в конечном счете входят и которого они, лишенные своего «негативного» аспекта, суть составные элементы, как и всякое другое; в результате «пагубным» является лишь ограничение, необходимо обуславливающее любое случайное существование. ... «Пагубный» аспект полностью исчезает, потому что

${ }^{18}$ Генон Р. Царство количества и знамения времени. C. 295 . 
по существу он был лишь иллюзией, присущей «разделению». Только, по правде говоря, тогда уже нельзя говорить собственно о «благоприятном», а тем более о «пагубном», поскольку эти два термина существенным образом коррелятивны и обозначают оппозицию, которая больше не существует, потому что, как и всякая оппозиция, она принадлежит к относительной и ограниченной сфере; как только она превзойдена, тогда просто есть то, что есть, и что не может не быть или же быть иным, чем оно есть; и таким образом, если хотят дойти до реальности самого глубоко порядка, то можно сказать со всей строгостью, что конец мира никогда не есть и никогда не может быть чем-нибудь другим, кроме как концом иллюзии» ${ }^{19}$.

Все дефекты и пороки в последнее время перед «барьером» достигают своего максимума; если что-то должно быть проявлено, может быть самое ущербное и недостойное существования (например, болезнь человека во всей ее красе перед уходом его из жизни), проявляется как бы по формуле Лейбница относительно лучшего из возможных миров, преимущество которого, то есть нашего мира, состоит только в том, что в нем исчерпаны все возможности существования, в том числе реализована и сама эта возможность, - поскольку этот наш мир существует. В мире «у барьера» с нагнетанием всевозможных проблем, решение которых (преимущественно механическим путем) порождает все новые, неслыханные проблемы, как бы размножая их, подобно тому, как хирургическая онкологическая операция рассеивает метастазы в больном организме ${ }^{20}$. Этот процесс порождает хаос, или мир наизнанку. Людвиг Тик, придумавший такой термин, мог еще представлять «мир наизнанку» иронически, теперь же он обернулся своей зловещей стороной. Теперь он просто, будучи отпечатком контртрадиции, отвращает, как Люцифер в Дантовом «Аде», сквозь который, однако, придется пройти, чтобы добраться до Чистилища. Этому миру-аду присуща внеположенность всего со всем, не «всего во всем», а только «в каждом особым образом». Распад сменяется кратковременным центрированием в фальшивом «Священном Царстве» (мир как бы схвачен, зацементирован, но неустойчив),

\footnotetext{
${ }_{19}$ Там же. С. 296-297.

${ }^{20}$ «Это не всегда так. Да и не в операции дело, просто операция не уничтожает «зерно» болезни» (Безуглов В. В.)
}

и затем мир переворачивается, как подтаявший айсберг, поменяв свои полюса.

Нынешнее состояние человечества, начавшееся не сегодня и не вчера, а с наступлением исторического времени (времени Великой Битвы), когда были посеяны первые семена разделения вместо изначального синтеза (все во всем, но ...). Об этом синтезе у нас нет достоверных сведений, следовательно, и представления, а только знание того, что вначале был золотой век, значит, золотой век должен быть и в конце, но только «за барьером», в запредельном, по ту сторону. Ясно, что «конец мира» есть также и конец Великой Битвы, в которой все, что существует по видимости особым образом, сражается между собой и в себе с собою, останется на поле битвы, по эту сторону «барьера». Вражда и Любовь правят миром, считали древние; так Вражда не может переступить черту. Определение жизни как борьбы представляется самоочевидным. Тотальная война считается неистребимой реальностью, потому что якобы человек по природе таков. И эта позиция с настойчивостью принимается исходной при всяком рассуждении и рассмотрении, на самом же деле это самая упорная иллюзия, в жертву которой приносятся живые существа.

В каждом событии представлен - раз все во всем - весь ход истории, истории Вселенной, человечества, народа и отдельного человека, хотя и неразличимо, поскольку весь информационный объем события остается скрытым в общем информационном поле, наподобие событий в живом организме. Мы видим, ощущаем, имеем дело и имеем в виду все только через события, происходящие в нашем физическом теле. Здесь каждое событие определено всем организмом, и каждая клеточка организма «знает» обо всем происходящем, откликается. В сознании же всплывает только бледный отпечаток всего «тотального» объема события, который остается за горизонтом, вне нашего сознания. Фильтры работают и по отношению к миру нашего организма, как они работают и для внешней среды, иначе мы просто не могли бы жить.

Точно также мы не можем определить тот негативный центр, который вытягивает на себя естественные силы организма (и по аналогии и в других масштабах жизни вплоть до масштаба Вселенной), мы осознаем и знаем только слабые его отпечатки, симптомы. Для тотального видения-знания нужно другое зрение-понимание. Х. Борхес в рассказе «Бес- 
смертные» говорит о Городе бессмертных, чудовищном и непонятном, достичь которого трудно, но и в нем нельзя находиться. «Не город, а пародия, нечто перевернутое с ног на голову и одновременно храм неразумным богам, которые правят миром, но о которых мы знаем только одно: они не похожи на людей» 21. Он был древнее самой Земли. «Этот Город ... ужасен; одно то, что он есть и продолжает быть, даже затерянным в потаенном сердце пустыни, заражает и губит прошлое и будущее, бросает тень за звезды. Пока он есть, никто в мире не познает счастья и смысла

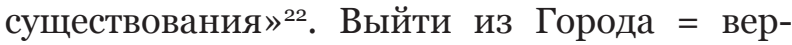
нуться к жизни.

Возвращаясь к «барьеру», можно сказать по аналогии, что пресечение барьера подобно пересечению смертной границы при жизни. Таковую пересекают не только посвященные, дважды рожденные, но вообще многие люди. Это люди, преодолевшие смертельную болезнь без посторонней помощи. Но есть и другие способы прохождения смертной границы при жизни, ведущие к контрпосвящению, их используют слуги инфернального мира, всевозможные не «светлые», а «серые«» 23 и «черные», святые Сатаны, как их называют. Здесь тоже есть передача некого влияния, и тоже духовного. Только эти «духи» полагают себя противниками Единой Традиции.

Традиция и посвящения, перестав в западной культуре быть священными и универсальными, уйдя из жизни общества, перемещаются в литературу и рассыпаются во

\footnotetext{
${ }^{21}$ Борхес X. . Л. Соч. в 3 т. Т. 1. М., 1997. С.425-426.

${ }^{22}$ Там же. С. 423.

${ }^{23}$ Квалификация подобных явлений не есть моя выдумка. Художники вообще особенно чувствительны к таковым явлениям тонкого мира (а это суть энергетические сгустки тонкого мира или психические остатки, как их раньше называли исследователи, например, Э.Леви). Не говоря уже о Стругацких, где фигурируют такие персонажи; но я хочу назвать удивительную и незабываемую картину Натальи Гончаровой, на которой изображены два ужасных насекомых, обглоданный куст некогда красивого цветка, на ветке которого сидит огромная гусеница. Они чудовищны не по величине или форме, которые самые «обычные», а по выражению «лица», иначе и не скажешь. Взгляд этих "ребят» по-человечески нечеловеческий, жестокий и безжалостный и, одновременно поразительно нейтральный. Они - серые. Это удивительное прозрение, несмотря на, казалось бы, простой сюжет. Но обычно художники, чтобы изобразить что-то ужасное, прибегают к простым приемам, не достигая эффекта прозрения в тонкий мир.
}

всевозможных обрывках в виде обычаев, верований, примет и суеверий, то есть обретают странный или даже гротескный облик. «Философ» Хома Брут в «Вийе» Гоголя Н. В. находясь в церкви и читая над мертвой Панночкой молитвы, воспроизводит в сильно гротескной форме именно ритуал посвящения, заканчивающийся, как и положено в перевернутом мире не символической, а реальной смертью. Гротеском - а современная псевдотрадиционная тенденция в литературе, в кино, вообще в культуре, использующая традиционные символы профанным образом, сводя все к грубой магии, понятой как мораль и борьба за власть, - завершается процесс десакрализации культуры. Начало этого процесса «олитературивания» традиции и посвящения в европейской культуре относится к XII веку. В средние века: «Символику и намеки на обряды посвящения можно найти в процессах Тамплиеров и других «еретиков» и даже в судах над ведьмами. Но эти посвящения, в той мере, в какой они еще действительно практиковались, касались узких кругов и были окутаны строжайшей тайной. Мы присутствуем если не при полном общем исчезновении посвящений, то при их почти окончательном сокрытии. Это обстоятельство привносит тем больший интерес к присутствию многих мотивов посвящения в литературе, которая складывалась, начиная с XII века, особенно в Бретонском цикле, и в первую очередь в романах об Артуре, КоролеРыбаке, Персифале и других героях легенды о Граале.... В правилах допуска в группу воинов, руководимую Артуром, можно расшифровать некоторые испытания при вступлении в тайное общество типа «мужского союза». ... В замке Грааля Персифаль должен провести ночь в часовне, где покоится мертвый рыцарь; раздается гром, и он видит черную руку, которая гасит единственный горящий светильник» 24 Среди тайных обществ было братство «Верные Любви», тоже не чуждое «литературе», включающее в себя посвящение. «Представители этого движения засвидетельствованы в XII веке в Провансе и Италии, во Франции и Бельгии. «Верные Любви» составили тайное духовное воинство, целью которого был культ «Единственной Женщины» и посвящение в тайну любви. ... Для нас «Верные Любви» представляют интерес, потому что они иллюстрируют явление, суть которого может быть выражена следующим

24 Элиаде М. Тайные общества: Обряды инициации и посвящения. М., 2002. С. 399-310. 
образом: передача тайного духовного знания через «литературу». Данте - самый знаменитый пример этой тенденции, которая предвосхитила нынешнюю тенденцию рассматривать искусство, особенно литературу, как образцовое средство, способное выражать идеи теологии, метафизики и даже сотериологии» ${ }^{25}$. Без Любви к «Единственной Женщине», то есть Высшей Мудрости, Данте понять нельзя. Начало было благородным.

Мирча Элиаде - замечательный исследователь традиции; хотя сам он не занимает трансцендентную точку зрения, тем не менее, суть традиции и посвящения и их метафизическое прикрепление прекрасно понимает, различая историческое и метафизическое измерение: «Как любое явление культуры, феномен посвящения - факт истории. Иными словами, конкретные выражения посвящения соотносятся как со структурой соответствующего общества, так и с его историей. Но вместе с тем посвящение предполагает экзистенциальный опыт: обрядовое испытание смертью и открытие сакрального; то есть оно существует в мета-культурном и транс-историческом измерении. ... Следует учитывать мета-культурный характер посвящения: одни и те же мотивы посвящения можно обнаруживать в мечтах и воображении как современного, так и первобытного человека. Повторяем, что речь идет об экзистенциальном опыте, присущем всему человечеству ${ }^{26}$. И это метафизическое измерение он соотносит с земной и психологической точки зрения: «Если мы можем сказать, что посвящение представляет собой измерение человеческого существования, то только потому, что оно отводит смерти позитивную роль: смерть готовит «новое рождение», чисто духовное, приводит к жизни, не подвластной опустошительному бегу Времени» ${ }^{27}$. В этом сходны все так называемые исторические традиции, то есть воплощения того или иного аспекта Единой Духовной Традиции. Что же в них проходит сквозь время? Это не формы, о которых думают, что чем они древнее, тем традиционнее. Передается только духовное влияние, или энергия, оживляющая все, к чему она прикоснется.

\section{Библиография:}

1. Борхес Х. . Л. Соч. в 3 т. Т. 1. М., 1997

2. Генон Р. Великая триада. М., 2010

3. Генон Р. Заметки о посвящении. М., 2010

4. Генон Р. Общее введение в изучение индуистских доктрин. Раздел второй. Главы III по VI // Ориентиры... Вып. 9. М., 2012

5. Генон Р. Размышления об индуизме. М., 2003

6. Зорзи А. И свет во тьме светит... / Ориентиры... Вып. 9. М., 2012/

7. Генон Р. Царство количества и знамения времени. М., 2011

8. Коновалов С. С. 500 важных мыслей для здоровья и счастья. М., 2014

9. Элиаде М. Тайные общества: Обряды инициации и посвящения. М., 2002.

10. Элиаде М. История веры и религиозных идей. Соч. в 3-х т., М., 2012.

11. Услышь флейтиста. Суфии о суфизме. М., 1998

12. М.М. Прохоров История, культура определения бытия и гуманизма // Философия и культура. - 2012. - 2. - С. $51-61$.

13. Т. А. Шеркова Древнеегипетские храмовые тайники // Исторический журнал: научные исследования. 2012. - 5. - C. 104-110.

14. Копцева Н.П.. Проблема истины в философии религии. Специфика конгцептуализации истины в буддийской философии. // Философия и культура. - 2013. - № 11. - С. 1564-1573. DOI: 10.7256/19992793.2013.11.961

\section{References (transliterated):}

1. Borkhes Kh. . L. Soch. v 3 t. T. 1. M., 1997

2. Genon R. Velikaya triada. M., 2010

3. Genon R. Zametki o posvyashchenii. M., 2010

\footnotetext{
${ }^{25}$ Там же. С. 313-315.
}

${ }^{26}$ Там же. С. $320,-322$.

${ }_{27}$ Там же. С.332. 
4. Genon R. Obshchee vvedenie v izuchenie induistskikh doktrin. Razdel vtoroi. Glavy III po VI // Orientiry... Vyp. 9. M., 2012

5. Genon R. Razmyshleniya ob induizme. M., 2003

6. Zorzi A. I svet vo t'me svetit... / Orientiry... Vyp. 9. M., 2012/

7. Genon R. Tsarstvo kolichestva i znameniya vremeni. M., 2011

8. Konovalov S. S. 500 vazhnykh myslei dlya zdorov'ya i schast'ya. M., 2014

9. Eliade M. Tainye obshchestva: Obryady initsiatsii i posvyashcheniya. M., 2002.

10. Eliade M. Istoriya very i religioznykh idei. Soch. v 3-kh t., M., 2012.

11. Uslysh' fleitista. Sufii o sufizme. M., 1998

12. M.M. Prokhorov Istoriya, kul'tura opredeleniya bytiya i gumanizma // Filosofiya i kul'tura. - 2012. - 2. C. 51-61.

13. T. A. Sherkova Drevneegipetskie khramovye tainiki // Istoricheskii zhurnal: nauchnye issledovaniya. - 2012. 5. - C. 104-110.

14. Koptseva N.P.. Problema istiny v filosofii religii. Spetsifika kongtseptualizatsii istiny v buddiiskoi filosofii. // Filosofiya i kul’tura. - 2013. - № 11. - C. 1564-1573. DOI: 10.7256/1999-2793.2013.11.961 